This is the accepted manuscript of the article, which has been published in Leadership. 2019, 15(4), 461-479.

https://doi.org/10.1177/1742715018768707

\title{
Spacing leadership as an embodied and performative process
}

\author{
Ropo, A. \& Salovaara, P.
}

\begin{abstract}
Aligned with the recent stream of research on the materiality of organizing, in this article we develop a conceptualization of leadership as a sociomaterial relationship between human and space. We join the emerging discussions on the 'thing-ness' of leadership and extend these by addressing how an aesthetic, sense-based and embodied knowledge constitutes the sociomateriality of leadership and organizing. With the help of a Lefebvre-inspired framework, we introduce the concept of ‘spacing leadership’ that explicates leadership as being produced in an embodied and performative process between people and space. To specify this, we thematise three aesthetically embodied categories of knowledge development - senses, feelings and memories - to depict a sociomaterial understanding of leadership and space.
\end{abstract}

\section{Keywords}

Materiality, space, leadership, aesthetic epistemology, embodiment, process ontology, Lefebvre, performative 


\title{
Introduction
}

\author{
Ma'am I know you don't know me from Adam. \\ But these handprints on the front steps are mine. \\ And up those stairs, in that little back bedroom \\ is where I did my homework and I learned to play guitar. \\ And I bet you didn't know under that live oak \\ my favourite dog is buried in the yard. (...) \\ Won't take nothing but a memory \\ from the house that built me.
}

In the hit song The House That Built Me, released on the American country singer Miranda Lambert's 2010 album Revolution, the songwriters Douglas and Shamblin (2009) reverse the conventional relationship between people and houses: not only do people build houses, but houses build people, too. Winston Churchill shares the same view: 'We shape our buildings, and afterwards our buildings shape us' (in Yanow, 2010: 139). Granted, artists and politicians may have more freedom in their expressions than academics do, but lately, research has also recognized materiality as having an influence on human interaction, behaviour, identity and agency (Dale and Burrell, 2008; Latour, 2005; Miller, 2005, 2008; Taylor and Spicer, 2007; van Marrewijk and Yanow, 2010). Following on from this 'material turn', the impact that material objects and the built environment have on practices and organizing activities has also been conceptualized as leadership in leadership studies (Hawkins, 2015; Oborn et al., 2013; Pullen and Vachhani, 2013; Ropo et al., 2013; Sergi, 2016). The message from these studies on materiality and leadership resembles the song: human social interactions and knowledge about the self are embedded in the materiality of the environment and physical places. Alas, houses do build us.

But how do they do that? This article aims at conceptualizing human spatial engagement under the term ‘spacing leadership’. (see also Salovaara \& Ropo, 2018) Applying insights from Henri Lefebvre’s (1991, 2004) theorizing on space, particularly his concepts of lived space and embodied rhythmanalysis, we analyse three empirical work-related vignettes where 
spatiality has a profound impact on human actions, and the human, in the process, re-forms spatiality. While Lefebvre is the seminal figure in organizational space studies, our conceptualization is further indebted to Beyes and Steyaert (2011), who in a Lefebvre-inspired fashion, conceptualize space as active, dynamic and performing, and propose a verb form for this: spacing. In Crevani's (2015) words: 'Instead of space as a container 'already there', space is to be conceived as produced, always under construction.'

We connect these space-related discussions with current sociomaterial leadership studies on the 'thing-ness' and materiality of leadership (Hawkins, 2015; Oborn et al., 2013; Sergi, 2016; Zhang and Spicer, 2014) to create the concept of 'spacing leadership'. We propose that the intersection of leadership and space offers an ample instance for clarifying the sociomateriality of leadership from two thus far less-discussed, yet potentially beneficial perspectives: aesthetic epistemology and embodiment. While the concept of spacing leadership aligns with sociomaterial leadership studies, it also extends the discussions by addressing how an aesthetic, sense-based and embodied knowledge constitutes the sociomateriality of leadership and organizing. We formulate our research interest as follows: How does the embodied epistemology of spacing leadership through a Lefebvre-inspired framework contribute to debates on the sociomateriality in leadership?

The article proceeds as follows: We first outline discussions on the materiality and spatiality of leadership, and then proceed to show how linking space studies with process ontology has resulted in space being described in terms of dynamics, activity and performance. The article then turns to Lefebvre's triadic space model that has greatly influenced organizational studies on spaces. He emphasizes how the experience of space is, in the first place, an embodied one, which leads us to further discuss embodiment and aesthetic epistemology to address the sociomaterial conceptualization of leadership. Next, we illustrate three vignettes to empirically describe and analyse what spacing leadership is. To specify this, 
we thematise three aesthetically embodied categories of knowledge development, senses, feelings and memories, to depict a sociomaterial understanding of leadership and space. We finish the article by reflecting on ethical issues in regard to materiality at large: the environment.

\section{Materiality and spatiality in leadership}

Materiality has been included in leadership studies in different ways. Most commonly, materiality is viewed as embodiment and as being specifically attached to the bodies of leaders, referring to their physical presence, appearance, identity or bodily gestures (e.g. Bathurst and Cain, 2013; Fisher and Reiser Robbins, 2015; Ford et al. 2017; Ladkin and Taylor, 2014; Melina et al., 2013; Pullen and Vachhani, 2013; Ropo and Sauer, 2008; Sinclair, 2005, 2013). Here, materiality and embodiment predominantly concern leaders, followers and their relations. Also, the terms 'leader’ and 'leadership’ are typically set equal, thus contributing to - and popularizing - notions like 'leaders embody leadership', 'leaders embody the capacity to lead' or 'leadership embodiment tools'.

The view presented in this paper on leadership materiality takes quite a different route. First, we will use embodiment in what follows as the key for conceptualizing human spatial engagement as leadership, but to be quite clear, here embodiment refers to an aesthetic, sensebased epistemology related to ways of knowing (not to a leader's body, appearance or body language) (Hansen et al., 2007; Ropo and Parviainen, 2001; Salovaara and Ropo, 2013). Second, instead of relying on the notion of leaders doing leadership, our view of leadership is post-heroic and plural: many people, collectives and groups, and even materiality, contribute to leadership (Crevani et al., 2010; Denis et al., 2012). Third, we explore leadership as constructed and performed in a process where people are being led by their felt experiences on the physical spaces. The processual view of leadership does not regard leadership as an 
entity, but something that emerges from interactions and that is constantly shaping and being shaped. Fourth, although organization research prioritizes human mental functions over bodily ones (Ropo et al., 2013), from a phenomenological perspective, an everyday connection to space is that of an embodied attachment, not that of a distant, rational disembodied observer (Merleau-Ponty, 2012). In sum, when, in what follows, the paper refers to space and embodiment, it associates the connection with these premises on embodiment.

Now, in terms of its interest in materiality, leadership research follows the shift that has taken place in organization studies. There is a growing sensitivity to materiality and physical objects transforming 'how social actors interact with each other' (Orlikowski, 2007: 123). This is evidenced in organization studies in how, for instance, water coolers, copy machines or smart phones impact people's daily interactions and identity (Fayard and Weeks, 2007; Humphries and Smith, 2014; Orr, 1995; Symon and Pritchard, 2015). Several studies have advanced this proposition in various spatial contexts ranging from hospitals, bookstores, coworking spaces, offices and virtual work to homes and houses (Clegg \& Kornberger, 2006; Dale and Burrell, 2008, 2015; Ropo et al., 2013, 2015; van Marrewijk and Yanow, 2010). As Oborn et al. (2013) observe, in an office environment, a plenitude of mundane material objects contributes to leadership:

Leadership enactment entails engaging with materiality - for example, offices, meeting rooms, desks, computers, reports, email distribution lists. (...) We argue that multiple actors, data sheets, structures of accountability, specialized knowledge, technological resources, protocols and workshop rooms come together to enact leadership in formulating policy. (Oborn et al., 2013: 256)

This shift towards acknowledging the role materiality and spatiality play in organizing 
activities goes for leadership research, as well. Hawkins (2015) claims that there has been an absence of things in leadership studies, but 'it is becoming clear that leadership is materialized through inter alia human bodily performances, architecture, clothing and other artifacts' (p. 952).

Acknowledging how materiality enacts leadership requires connecting three recent developments in leadership research that stress the plural, processual and material nature of leadership. First, leadership is no longer only attached to individual leader or follower qualities, but is practised informally by many, thus highlighting how leadership is also a multiple and plural phenomenon by nature (Denis et al., 2012; Parry and Bryman, 2006; Raelin, 2011; Wood, 2005). Second, the process ontological approach has been applied to leadership studies lately, where a shift from the 'being of leadership' towards 'leadership as becoming’ can be observed (Crevani et al., 2010; Dachler and Hosking, 1995; Draht et al., 2008; Wood, 2005). Here, leadership is seen as an ongoing and dispersed organizational activity where a myriad (social and material) of intermingling influences develop as a function of time and 'lead' to something. Third, we identify leadership as an emerging interaction process being shaped in and by everyday practices and the material environment. In a similar vein, Sergi (2016) includes materiality as a key dimension to leadership(-as-practice) and emphasizes the processual and collective nature of leadership. Thus, 'spacing leadership' refers to the constant dynamics of how people and space interact, regardless of whether this connection is explicated or not.

When studying space in terms of leadership, our focus is on the fluid character of space (Crevani, 2015), and 'on the process of sociomaterial entanglement, not the outcome of it', as Leonardi (2013a: 162) puts it. Physical spaces and places have been shown to influence human action, either directly, indirectly, symbolically or through evoking emotions (De Vaujany and Vaast, 2013; Kastelein, 2014; Ropo et al., 2013; van Marrewijk and Yanow, 2010; Wasserman 
and Frenkel, 2015; Zhang and Spicer, 2014). In these studies space is not given an independent agency but is treated in relation to human engagement: we need to give a voice to space (Yanow, 2010), read the ruins (Dale and Burrell, 2011) and listen to the walls talk (De Vaujany and Vaast, 2014). The physical features, traces, marks on paint, wood or stone - as in the country song: 'handprints on the front steps' - come alive and gain in meaning when read by humans. Space activates memory, and memories or associations can turn entering space into an active, resonant and vibrant experience.

Yet despite this seemingly lucid influence of spaces on humans, here this relation is not regarded as a 'strong', direct material influence on humans, but rather as a sociomaterial one where the social and material form simultaneously and interdependently. To describe the reciprocity of this concept, several terms have been proposed: the social and material are intrinsically/inherently entangled, i.e. inseparable (Carlile et al., 2013; Orlikowski, 2007), interpenetrative (Barad, 2003), intertwined (Jones, 2013), intertwined and mutually enacted (Dale, 2005), constitutively entangled (Orlikowski and Scott, 2008), or mutually constitutive (De Vaujany and Vaast, 2014; Hernes et al., 2006; Michel, 2014; van Marrewijk and Yanow, 2010). This manifold terminology reflects how theoretical/conceptual the discussions on sociomateriality have become, Leonardi (2013b) points out.

While organization studies have had difficulty in theorizing on how the human and material relate, the experience of space has been thematised in, for instance, human geography. Tuan (1977) studied how people in various cultures think and feel about spaces and how those unpronounced concepts influence their actions in space. The construction of spatial reality has consequences, he argues. Massey (2005) emphasizes how space is not a frozen thing, but there is movement and fluidity to nature and the built environment. While nature in general has not typically been included in leadership conceptualizations, ‘environmental leadership' nowadays shows a growing concern with how the environment has been acted upon, mainly 
(ab)used (Redekop, 2010). Also sociomaterial studies note this ethical concern: a passive or neutral stand towards materiality may more easily accept exploitation (Carlile et al., 2013; Introna, 2013). This article joins a material-ethical agenda according to which we should not be indifferent to materiality or the ways in which it becomes included in our conceptualizations.

To further this more inclusive agenda, the following two sections address an ontological and epistemological issue that the entire spacing leadership concept relies on: understanding spatial performance as a performative process, and as an aesthetic and embodied engagement.

\section{Space as performing}

Recently, research emphasizing how mundane practices and interactions produce leadership has configured the role of materiality through artefacts (Carroll, 2016; Carroll et al., 2008; Crevani et al., 2010; Raelin, 2016) and the 'lived' experience of material things (Crevani and Endrissat, 2016: 31-32). Theoretical debates around materiality have 'made a convincing case for the need to acknowledge the performative role of materials in social affairs', Carlile et al. (2013: 6-7) claim.

The question, then, is not whether space influences social interaction, but how. In our conceptualization, we follow Beyes and Steyaert (2011), who note the processual nature of space: human spatial entanglement is not a momentary event or static entity, but something that evolves and changes over time. In discussing a video-based art work that shows an event - a crowd of people seemingly unexpectedly being in the middle of an 'extremely powerful gush of water' (Beyes and Steyaert, 2011: 46) - in extreme slow motion, they suggest the verb form 'spacing' to illustrate the various aspects and influences that space is continuously performing. Spacing 'implies exchanging a vocabulary of stasis, representation, reification and closure with one of intensities, capacities and forces; rhythms, cycles, encounters, events, movements and flows; instincts, affects, atmospheres and auras; relations, knots and 
assemblages' (Beyes and Steyaert, 2011: 47). Through listening, experiencing and memorizing, space is experienced and influences individuals in many ways, which makes it multiple (Hernes, 2004). Similarly to a theatre play that is never repeated in exactly the same fashion, the performance of space is constant, but never repetitive. The term 'spacing leadership' highlights this eventful, active, dynamic performing character of space that influences human actors in their interactions with themselves, with each other, with artefacts and with the space.

To discuss how the ongoing performative process unfolds, we apply process organization studies. Using process terminology, human spatial engagement can be described as a process of becoming, a continuation of micro-activities where both the space and humans are in constant movement, change and perpetual emergence (Chia and Holt, 2006; Hernes, 2014; Langley et al., 2013; Tsoukas and Chia, 2002). For our purpose in this paper, one can distinguish between three currents in process research at large: the 'weak' and the 'strong' process orientation, a part of which is the 'performative' view (Langley and Tsoukas, 2016). The weak orientation regards a process as a change from one form to another, or as Feldman (2016) puts it: it focuses on the arrows between boxes. From this perspective, the fluid character can be followed chronologically and is regarded 'as something that happens to organizations viewed as relatively stable entities' (Langley and Tsoukas, 2016: 3). But as we have already defined spacing as something constantly evolving, our definition relies on the idea of change and movement taking place on a more profound basis. The performative view describes an ontological stance according to which the reality is fluid and constantly becoming. The strong process approach sees that this change is not something that only happens, but that is actively constructed by agentic actions. While we consider space as something that (as in the lyrics from the opening country song) can 'build' us, we feel committed to the strong performative approach. In performance, the social and material are 'ontologically inseparable' 
in two ways: there is socialness to things and thingness to social order (Carlile et al., 2013: 8).

Applying that formulation we claim that there is leadership to spatiality and spatiality to leadership. When we grow in places that have a profound impact on what we have become, then places and buildings build us, as noted in several studies above. Space performs leadership as a combination of various events that we associate with material places (properly or not).

To consider space as a process evolving in time means that the space a person engages with is not one and the same for each encounter. Time leaves marks on materials and surfaces, and it shows wear and tear, patina, from daily use. The same physical space can create various reactions: at times it can feel inspiring and exciting, at other times boring or even frightening (Elsbach and Pratt, 2007; Ropo and Höykinpuro, 2017).

The main inspiration in organization studies for including this kind of lived experience into the concept of space has been the French sociologist and philosopher Henri Lefebvre. In his major work The Production of Space (1991), Lefebvre argued that space should not be regarded solely in abstract architectural qualities, as an object measured in numbers and figures, but as a social production. For this purpose, he distinguishes between three kinds of spaces: conceived, perceived and lived space (Lefebvre, 1991). The conceived space refers to space as an object 'out there', and it is accounted for in abstract geometrical and mathematical measures. Taylor and Spicer (2007) call conceived space the 'planned space', the way it is represented, for instance, in architectural sketches and in 3D renderings. The next element, perceived space, implies how people actually practice the space: no matter the plans, spaces can be practically used in very different ways. The third element within the triadic model, 'lived space', is based on the embodied experience of space: this is how people feel it, how they perceive it, how they relate to it personally, socially or culturally. Though analytically separate, each of the components is simultaneously valid. Zhang (2006) uses the term 'shifting 
perspectives' to explain the relations between these three:

We might compare conceived space, perceived space and lived space as three cameras projecting simultaneously onto any organisational event. (...) through the first camera we read mathematical data, the height of the man, the length of a corridor, and so on; through the second we see the body movement of the man, his walking about, his gestures; and through the third, we reach into his inner subjectivity, his feeling about the stupid doorknob which wouldn’t turn, for instance. (Zhang, 2006: 222)

The last one, the lived space, is maybe currently the most interesting part of Lefebvre's triad, because it underlines how conceptualizing space is incomplete without the individual and social meanings attached to it. Linking perceived and lived space means focusing on the moving, acting, feeling, thinking human within the space. Spacing is experienced as an activity, not an entity, and therefore it should not be designed or planned as an entity, either. To further refine this understanding, we next discuss the embodied experience of space.

\section{The embodied experience in spacing leadership}

Central to understanding the dynamic character of 'spacing leadership' is to see how it is epistemologically based on embodied experience. For Lefebvre, the 'understanding of space ... must begin with the lived and the body, that is, from a space occupied by an organic, living, and thinking being' (Lefebvre, 1991: 229). Theorizing about space is to be considered 'through the body, not in a flight away from it' (Braidotti, 2002: 5). It is through the organic human engagement with space that the messy rhythms of everyday life, where all is mobile and fluctuous, become included in the concept of spacing. We term the human embodied relation to space as 'spacing' because of the processual nature of the relation, where both 
mutually influence and constitute each other. The basic argument we now want to develop, and later describe in vignettes, is that spacing leadership is epistemologically based on sensebased observations, emotions, experiences, memories and intuitions, on gut feelings (aesthetic epistemology). Not everything we experience is epistemologically fully explicable (Ropo et al., 2013), and the connections a space evokes can be surprising, unexpected, even enigmatic. We are not always able to provide convincing reasons as to why we like or dislike something - but we can work on it. And as in the country song, often these references and meanings are invisible or even incomprehensible to outsiders: 'in that little back bedroom/ is where I did my homework and I learned to play guitar'. Therefore, again, spacing leadership cannot be captured in a single snapshot, but needs to be fashioned as an evolving process that has past, present and future, as Hernes (2014) describes.

The lived experience of space can be further explained by paying attention to how Lefebvre in his Rhythmanalysis (2004) approached knowledge created by humans as embodied beings:

The body. Our body. So neglected in philosophy that it ends up speaking its mind and kicking up a fuss. Left to physiology and medicine ... The body consists of a bundle of rhythms, different but in tune. It is not only in music that one produces perfect harmonies. The body produces a garland of rhythms. (Lefebvre, 2004: 20)

For Lefebvre, humans think with and through their bodies.

The rhythmanalyst calls on all his senses. He draws on his breathing, the circulation of his blood, the beatings of his heart and the delivery of his speech as landmarks. Without privileging any one of these sensations, raised by him in the perception of rhythms, to the 
detriment of any other. He thinks with his body, not in the abstract, but in lived temporality. (Lefebvre, 2004: 21)

The lived temporality is not a product of the moment, but a continuous chain of impressions and sensations, and of reactions to these. Embodiment is thus not only a sense organ at the receiving end, but a co-producer of reality, and, as such, an epistemological tool for the space researcher. That is how humans and spaces come to a performative relation with each other.

The radicality of an embodied approach to knowledge needs to be considered against the background of organization studies' complicated relation with embodied knowledge. There has been a 'discomfort with bodies and embodied meaning' (Yanow, 2010: 147) in organization studies in general and in leadership studies in particular (Ropo et al., 2002, 2013; Sinclair, 2005). Leadership has been over-cognitivized, Pullen and Vacchani (2013) claim. Lefebvre's concept of lived space contributes to this critical view, also, as Merrifield (2000) explains:

Lefebvre knows too well ... that the social space of lived experience gets crushed and vanquished by an abstract conceived space. In our society, in other words, what is lived and perceived is of secondary importance compared to what is conceived. (...) Conceptions, it seems, rule our lives, sometimes for the good, but more often - given the structure of society - to our detriment. (Merrifield, 2000: 175)

This quote underlines that spacing leadership, as a concept combining spatial and human interaction, is easily at risk of being understood in terms of deterministic terms, as if space did something in itself, objectively, to human relations. As it rather emphasizes the lived and perceived, it functions as a cultural-critical term towards commodifying human spatial 
engagement. Our argumentation for spaces performing leadership ('spacing leadership’) stems from aesthetic epistemology in leadership and organization studies (Hansen et al., 2007; Ladkin and Taylor, 2010; Linstead and Höpfl, 2000; Ropo et al., 2013; Ropo and Parviainen, 2001; Strati, 1999). The aesthetic approach acknowledges sensory knowledge, embodied emotions and felt experience as legitimate forms of knowledge (Strati, 2007), which defines that aesthetics is an epistemological stance, not related to beauty or art (Hansen et al., 2007). Based on the above, and following Ropo and Parviainen (2001), we argue that knowledge about the leadership of space has a bodily dimension. This we now want to illustrate with three empirical vignettes.

\section{Illustrations: Spacing leadership}

In terms of methodology, our analysis is based on empirical vignettes that serve the same function as Puranam et al.’s (2014) illustrations: ‘These illustrations are not meant to be an exhaustive list (...); our objective here is conceptual clarity rather than empirical validation, so these examples help primarily to explain our arguments rather than offer evidence for them' (Puranam et al., 2014: 163). The vignettes are meant as illustrations to explain what we mean by the concept of spacing leadership, and, as such, they neither aim at providing full empirical validation, nor were they analysed in that fashion.

The vignettes are drawn from a 46-minute documentary film 'Leadership in Spaces and Places’ (Salovaara, 2014: https://vimeo.com/95709554) that explores leadership in various spatial environments ranging from offices to a chapel, theatre, orienteering in the woods, and to dry docks and shipbuilding. In the film, the space is narrated both visually and through the accounts of the informants: how they practice in and feel about the space and how their way of being is entangled with the spatial context. To depict different aspects of embodied experience of space, we chose three vignettes from the film to illustrate spacing leadership: an 
actor in a theatre, a shipbuilder and electricians in a dry dock. We then constructed our narratives of spacing leadership. The vignettes connect the informants to our professional narrative that views leadership through aesthetic epistemology. Both the informants' and our felt senses, emotions and memories were employed (Strati, 2007). We used our 'full sensory variety' to watch the film and capture its affective data (Wood et al., 2018). We followed what Cunliffe and Coupland (2011: 64) call embodied narrative sensemaking, where embodiment refers to bodily sensations, felt experiences, emotions and sensory knowing.

Our analysis follows a phenomenological and hermeneutic tradition on narrative research that privileges experience and the way people make sense of themselves and relations in context (e.g. Meretoja, 2014; Squire, 2013) rather than focusing on sequenced events (Riessman, 2008). Knowledge is achieved in narrations on self and space through felt experiences. As discussed earlier, we draw here on the aesthetic organization and leadership theory (e.g. Hansen et al., 2007; Ropo et al., 2002; Strati, 1999) that pursues knowledge development based on senses rather than pure logic.

Through a thematic analysis of the vignettes, we brought to the fore three aesthetic and embodied categories based on what the informants emphasized and how they spoke about the spaces, their spatial practices and their experiences of the space: How the actor found the stage of the theatre the safest place to sleep before the opening night (emotional category); how the shipbuilder needed to physically sense the materiality of the assembly hall (sensuous category); and how the electricians acknowledged the value of past expertise (memories/history category). These aesthetic categories are not exclusive, but overlapping, and construct the phenomenon of spacing leadership.

Let us listen to the stories of the informants next.

Vignette 1: Actor in the theatre - 'The safest place is the stage' 
We were all young and newcomers in this theatre. The opening night was to be the next day. We had no rehearsals that day, surprisingly. It was a terrible feeling. I had not slept at night at home. I was really tired and wondered what to do, since I was going to be on stage that evening. I came here [points to a rather crude and uninviting stage with a dark, seemingly hard floor and red and white pillars not so carefully painted, fallen cabinets, raw wooden boards and ladders left standing carelessly], I grabbed a mattress and blanket and slept really well here on stage. So, the safest place was the stage. Earlier at home, all I was thinking [about] was the play, but here I did not think of the play at all. I fell asleep fast.

It is typical to think that the stage is a holy place to work, but I think it is the informal part that matters most [walks backstage crossing a multitude of technical equipment towards the actors' rooms that are messy with tons of theatre materials, through narrow corridors and steep stairs, finally to a tiny green room where all the workers socialize and have coffee]. Here you can hear what's going on. Everything is connected to this space. This space forces [you] to interact. What is said here goes eventually to the production. We have no room for concentrating. There is absolutely no creative or inspirational space here. And that is not at all the point. [Laughs and points to worn-out furniture, dirty coffee mugs and bleak colours]. (Actor in Salovaara, 2014: 26:21)

Here, the actor explains his relationship with the theatre space. The anticipation and excitement before the opening night grew and even his home did not provide a tranquil space for resting, although research suggests otherwise (e.g. Buttimer and Seamon, 1980/2015; Seamon, 1979/2015). While the space seemed to have instilled both fear and insecurity (Fineman, 2000; Ropo and Höykinpuro, 2017; Tuan, 1977) in regard to the outcome of the 
play, simultaneously it was the same physical environment where the rough interior (Strati, 1999), mundane interactions, talks and experiences during rehearsals gave him the feeling of ultimate safety. Of all the spaces, he laid down on the dark stage - and fell asleep. While sleeping on a mattress on the open stage, his fear turned into comfort, and he felt safe, maybe even sacred (Strati, 1999). This is similar to what Springborg (2010) refers to as sense-making based on present sensing (instead of basing one’s actions on past concepts): in the actor's case the sense-based experience of being on the very familiar and thus safe stage overwhelmed the (irrational) feeling of fear of the future. The stage become a 'space of action' (Crevani, 2015) for re-constructing what it means to be an actor: to confront the very same space that evokes both the feelings of fear and safety.

Unlike typical institutional theatres, this experiential theatre did not have a carefully planned, architecturally designed space. On the contrary, the theatre was set up in a rugged basement that happened to be available and seemed reasonably suitable for theatre practice. What mattered most was the atmosphere of the place (Pallasmaa, 2014), community feeling (Cuba and Hummon, 1993) and doing things together. The cramped space, as the actor calls it, allowed for discussions around the play.

Vignette 2: Shipbuilder - 'You need to feel how the water runs'

When I start to build the boat, I see it as a final outcome. In my mind, I make a perfect image of it. I can see every detail. This is like a finished journey. To avoid the decay ... I want to make the water run off the deck as fast as possible. I have carved a drain here that leads the water this way [shows with hands and strokes the wooden surface back and forth]. This is how the water does not stay in the corners. This makes the boat last longer. The problem with this assembly hall is that it is rather dry [lifts his nose to sense the air]. Boats should be made in high humidity because when they are 
set to sea, they shift between two extremes ... That is an unpredictable factor. Every nook in the boat must be visible to me. Nothing must be hidden or pushed under the carpet. Quality, design and function form a unity. (Shipbuilder in Salovaara, 2014: $34: 18)$

The shipbuilder started by emphasizing how he carefully plans and anticipates ('conceives' in Lefebvre's terms) the outcome. As his story continues, it becomes clear that his work is fundamentally shaped by his previous experience and sensory knowledge (Hansen et al., 2007) of the materials, both the wood, the crafting tools and the qualities of the assembly hall, especially its level of humidity as he smells the air and senses the wooden material (Martin, 2002). He feels the shaped forms of the material in the movements of his hands by being in embodied touch with it as his hand strokes along the side of the boat, and his intense breathing aligns with the process. This resembles what Beyes and Steyaert (2011) write of as flows, instincts and movements. The shipbuilder's knowledge is very much tacit, embodied and sensible, cumulated in his expertise and craftsmanship (Ropo and Parviainen, 2001; Strati, 2007). With a sense of humility, he acknowledges that even after careful planning and crafting, the outcome cannot be predicted once the boat is moved between extreme spaces, from the dry assembly hall to the wet sea. The material boat and the experience of it are literally in a process of becoming (Hernes, 2014; Tsoukas and Chia, 2002). In terms of leadership, Crevani (2015) points to the ongoing processual nature of producing direction of action (a central definition of leadership) as a spatio-temporal concept.

Vignette 3: Electricians: 'You would be a barbarian to ignore your history'

[Two electricians walk towards an electricity centre in a still-used historic dry dock that originates in the 1750s. They open the door of an old building.] There is old 
machinery left. An old transformer - and that's the new one over there [points first to a big, old, dark grey wall of about 4 meters with control panels, and then to something we cannot see]. The meter panel is made for DC. And the guys that built it are far away now. Some people were about to dismantle it, but fortunately, someone, I think it was ... thought it should be saved. The pride in their craftsmanship has been an essence. Even the thickest cords have been beautifully installed; it is like a work of art. [The electricians go to an old switchboard that is located in a narrow space where the electricians have to be in very close physical proximity to the switches.] Safety is the reason for renovations. [Reaches out to a switch.] This is all in the open. See what a small space this is. If you stumble, there is not much room to escape. (...)

[They continue the dialogue in their messy and over-filled 'office'.] The will to do a quality job has to do with this place. The criteria are different on the mainland and here. You can't mix $21^{\text {st }}$ century technology with a wall built in 1750 just like that. It stays there for generations. It requires a sense of style. An old teacher of mine said: If you don’t know your country’s history, you're a barbarian. It’s part of your education to know about the past. Old objects talk to us. They have their own history.... They are worth saving. (Electricians in Salovaara, 2014: 38:47)

The electricians take a moment to reminisce about how the past way of planning electric panels forced the men to work in unsafe spaces and positions. This goes to show how their profession and its materiality have changed, how the spaces and machinery have evolved, and how they embody affect (Beyes and Steyaert, 2011). Emotional attachment to the history of the building and the embodied connection (physical touch) with the old machinery evokes empathy towards being protective of past achievements and treating them with respect (Bachelard, 1964; Low and Altman, 1992). 
Leadership research has evidenced a similar phenomenon of memory and traditions guiding the current actions. For instance, how the British Royal Navy seafaring heritage and ethos are purported on the land bases in the form of naval memorabilia, culture and references to ships (land bases are not called buildings but 'shore establishments') (Hawkins, 2015: 959); also, how the concept of 'backward reflexivity' in understanding aesthetic leadership explains that what we hear as music is understood only as a continuation of past, present and anticipation (Bathurst et al., 2010); and how school class-rooms are still dominated by the centuries old seating order that stresses the teacher's authority over pupils (Ropo et al., 2013: 389).

An empathic, sensitive connection to history creates a bridge between time, space and people. As the electricians saw aesthetic beauty (Strati, 1999) in the way the past colleagues had performed their work, that history became alive and gave direction to present thinking and actions. Appreciating the skills and the historical space they work in encourage them to do their very best job now. Working next to the past workers' skills, they did not want to look like 'barbarians' either. The pride in the work is shared, and it is seen and heard in the way they talk about their work. Living with the electric machines and their space also influenced the rhythm of their work (Strati, 1999); they were considerate and thoughtful, as mistakes would be fatal.

\section{Discussion and conclusions}

While 'being led' by materiality - such as offices, meeting rooms, desks, computers and reports (Oborn et al., 2013) - is an everyday experience, the role of materiality has largely gone unnoticed in the leadership literature. Apart from the discussions on sociomateriality in organization studies, materiality has seldom been conceived as leadership. The spacing leadership concept introduced in this article relates back to the material and spatial turns in 
organization studies, which have quite recently reached the leadership field as a discussion on materiality or 'thingness' in leadership (Hawkins, 2015; Salovaara \& Ropo, 2018). To explore how leadership could be conceived of as a sociomaterial phenomenon through the ways in which people and spaces engage with each other, we built on the aesthetic approach to organizations (e.g. Strati, 1999) by drawing on embodiment as epistemology. Thus, our perspective differs from the often-assumed view of materiality and embodiment referring to qualities and actions of physical bodies in leadership studies (e.g. the Special Issue on 'The Materiality of Leadership’ in Leadership, 2013; Ladkin and Taylor, 2014).

Regarding space studies, our conceptualization of spacing leadership (see also Salovaara and Ropo, 2018) is indebted to Lefebvre’s (1999) triadic concept of social space - conceived, perceived and lived -, where lived, experienced space was considered as a key element for understanding the relationship between space and people. Spacing becomes accounted for through 'embodied apprehensions of the everyday performing of organizational space’ (Beyes and Steyaert, 2011: 47). Our empirical illustrations on the embodied connection between people and space show that spacing comprises of rhythms, emotions, sensations, intensities and atmospheres. Spacing leadership is a concept that depicts human engagement with space, where space is performative and active, not a passive, empty, non-reflective container. Furthermore, the spacing leadership concept relies on the process ontology of becoming. Spacing leadership describes a phenomenon where people and space influence each other in a mutually constitutive way in an ongoing process. Not only are people active and performing, but also spaces perform in a dynamic and emerging fashion. However, spaces do not lead or influence independently, but need human engagement and people's embodied experience on the space, we argue.

How is spacing reflected in the above illustrations and what is spacing leadership in them? This effect is formulated by Hernes, Bakken and Olsen (2006) as follows: 'While space is 
what shapes action and inter-action, it is reshaped by actions and inter-actions in turn’ (44). Yanow (2010) describes it in a similar way by saying: 'After we have shaped our built spaces and after they have shaped us - we act right back on those shapes and that shaping' (142). While our illustrations of spacing leadership - the actor in the theatre, the shipbuilder and the electricians - may not represent the most typical work and workplaces, we can notice the same phenomenon in traditional office environments as well.

Our analysis points out three thematic categories that are profoundly aesthetic and embodied: senses, feelings and memories. Felt senses of the space were especially present in the shipbuilder's work, the ways in which he touched the wooden material, but also smelt the dry air of the assembly hall with the anticipation of potential problems later on in the process. Yanow (2010) emphasizes the 'feeling space and spatial sensibilities as subjective and largely non-verbal ways of knowing, achieved through the experiences' (139). Martin (2002) found that smells, sights, sounds and touch construct the understanding of elderly people's homes. People 'build' the houses through all their sensuous qualities, but also the houses 'build' the people through their lived experience of the space. The performative relationship is reciprocal and mutually constitutive. Even office environments are increasingly built and renovated to appeal to our senses in an attempt to produce creativity, community building and better interaction (De Paoli et al., 2017). While these are merely managerial manipulations, the attempted sensuous effect is similar.

Fineman (2000) has characterized organizations as 'emotional areas to capture the intense activity of lived emotion in organizational life' (1). He connects emotions and aesthetics with material objects by referring to expressions such as 'my miserable chair', 'that cosy room' or 'this depressive building' ... where 'the aesthetic captures feelings of form or flow that are experienced from the places and objects where people work' (Fineman, 2000: 2). Feeling emotions in and of space is a key element in producing leadership. Phenomenologically- 
oriented architects talk about architectural atmospheres that are recognized as 'spaces with a mood, or emotionally felt spaces’ (Böhm, 2014: 96). While exploring the sense of place and drawing from Bachelard and Merleau-Ponty, Pallasmaa (2014) criticizes modern architecture for its overemphasis on visuality and form. Instead, he emphasizes an experiential atmosphere that is 'the overarching perceptual, sensory, and emotive impression of space, setting, or social situation. (...) an experiential property or characteristic that is suspended between the object and the subject' (Pallasmaa, 2014: 19-21).

Memories and connectedness to history were elementary to the way in which the electricians talked about their experience of space. Their appreciation of the expertise of the past colleagues (aesthetic skilfulness and an unsafe working environment) grew into empathy. A sense of the historic place and its materials influenced their way of carrying out electrical instalments. Their aesthetic and embodied experience of space also involved ethical considerations.

Figure 1 summarizes the origins of the spacing leadership concept and its contributions to leadership theory. With this figure, we wish to form more dynamic relations between the origins of the concept and how it affects the way we approach leadership. Additionally to the theoretical re-configurations around sociomateriality, aesthetic epistemology and performing space, our study brings forth three aesthetically embodied categories: senses, feelings and memories that function as integral epistemological enablers and specify what spacing leadership entails in our analysis.

Figure 1 about here

Figure 1. Spacing leadership: Origins and contributions to leadership theory 
In summary, the spacing leadership concept introduced in this article contributes to leadership theory in the following ways. First, it develops the sociomaterial approach to leadership by specifying the relationship between the human and the material as embodied spatial engagement. That leads to the second contribution: Spacing leadership further develops sociomateriality from an aesthetic, felt experience perspective. To make sense of the spatial experience, an aesthetic epistemology is needed, because it provides the necessary sense-based and embodied concepts of knowledge, including emotional experiences and memories, for defining the phenomenon in more detail. Third, the adverb 'spacing' emphasizes the dynamic processual nature of human spatial engagement that has the capacity to impact social interaction and lead people. Fourth, our analysis brings to the fore three aesthetic and embodied categories to conceptualize the sociomaterial nature of spacing leadership: senses, feelings and memories. Spacing leadership does not mean that material spaces would lead in a determined and managerial sense, independent of human engagement, but, as discussed, through human embodied experiences, intuitive feelings and atmospheres, which are influenced by personal history and cultural associations. This conceptualization was developed based on Lefebvre’s concepts of perceived and lived space. There are human-space concepts in organizational studies, but the spacing leadership concept takes the sociomaterial analysis one step further in conceptualizing it as fundamentally based on embodied felt experience. Finally, our analysis extends the work of Lefebvre, a Marxist sociologist, toward conceiving his triadic space concept in a somewhat unexpected context, leadership. As we have noted elsewhere, 'while Lefebvre is not a leadership scholar, there is leadership in Lefebvre' (Salovaara and Ropo, 2018).

Understanding the human-material relationship as an aesthetic and embodied experience holds an inherent ethical undercurrent. Both aesthetics and ethics involve values. Thus, the aesthetics of materiality warrant an ethical stance: while materiality provides leadership in 
relation to humans, this leadership of the material world is supposed to be heard. However, for example, we have created ecological catastrophes by largely neglecting our close relation to materiality, space, environment and nature. Only when we set ourselves in embodied relation to nature does it begin to 'speak' to us. As long as we hold on to a separation of ourselves and the materiality around us, there is a temptation to treat nature, but also other human beings, in an instrumental fashion. We have developed ever-greater capacities to form and un-form the physical environment. When people act on these formations, they confirm the new formations and signify that these are - at least - as valuable as other things. The human 'being' forms and is informed by the materiality. Thus, spacing leadership is not only an academic concept developed on the drawing board, but a call for action: since in our human spatial engagement we are 'spacing' anyway, let us be conscious about how embodied we are in our environment and nature. Even if they cannot defend themselves, they should not be abused. Therefore, it is our responsibility to be mindful of, in the words of Introna (2013: 265), the 'ethics of things'.

\section{References}

Bachelard G (1964) The Poetics of Space. New York, NY: Orion.

Barad K (2003) Posthumanist performativity: Toward an understanding of how matter comes to matter. Signs: Journal of Women in Culture and Society 28(3): 801-831.

Bathurst R and Cain T (2013) Embodied leadership: The aesthetics of gesture. Leadership 9(3): 358-377.

Bathurst R, Jackson B and Statler M (2010) Leading aesthetically in uncertain times. Leadership 6(3): 311-330.

Beyes T and Steyaert C (2011) Spacing organization: Non-representational theory and performing organizational space. Organization 19(1): 45-61. 
Braidotti R (2002) Metamorphoses: Towards a Feminist Theory of Becoming. Cambridge, UK: Polity Press.

Buttimer A and Seamon D (eds) (1980/2015) The Human Experience of Space and Place. Abingdon, UK and New York, NY: Routledge.

Böhm G (2014) Urban atmosphere: Charting new directions for architecture and urban planning. In: Borch C (ed) Architectural Atmospheres: On the Experience and Politics of Architecture. Basel, Germany: Birkhäuser, pp. 42-59.

Carlile P, Nicolini D, Langley A and Tsoukas H (2013). How matter matters: Objects, artifacts and materiality in organization studies. In: Carlile P, Nicolini D, Langley A and Tsoukas H (eds) How Matter Matters: Objects, Artifacts and Materiality in Organization Studies. Oxford, UK: Oxford University Press, pp. 1-15.

Carroll BJ (2016) Leadership as identity. In: Raelin J (ed) Leadership-As-Practice: Theory and Application. New York, NY: Routledge, pp. 91-109.

Carroll BJ, Levy L and Richmond D (2008) Leadership as practice: Challenging the competency paradigm. Leadership 4: 363-379.

Chia R and Holt R (2006) Strategy as practical coping: A Heideggerian perspective. Organization Studies 27(5): 635-655.

Clegg, S R and Kornberger, M (Eds.) (2006) Space, organizations and management theory. Frederiksberg C: Liber \& Copenhagen Business School Press.

Crevani L (2015) Is there leadership in a fluid world? Exploring the ongoing production of direction in organizing. Leadership 14(1): 83-109.

Crevani L and Endrissat N (2016) Mapping the leadership-as-practice terrain: Comparative elements. In: Raelin J (ed) Leadership-As-Practice. Theory and Application. New York, NY: Routledge, pp. 21-49. 
Crevani L, Lindgren M and Packendorff J (2010) Leadership not leaders: On the study of leadership as practices and interactions. Scandinavian Journal of Management 26(1): 77-86.

Cuba L and Hummon DL (1993) A place to call home: Identification with dwelling, community, and region. Sociological Quarterly 34(1): 111-131.

Cunliffe A and Coupland C (2011) From hero to villain to hero: Making experience sensible through embodied narrative sensemaking. Human Relations 65(1): 63-88.

Dachler HP and Hosking DM (1995) The primacy of relations in socially constructing organizational realities. In: Hosking DM, Dachler HP and Gergen KJ (eds) Management and Organisation: Relational Perspectives. Avebury, UK: Ashgate, pp. 1-29.

Dale K (2005) Building a social materiality: Spatial and embodied politics in organizational control. Organization 12(5): 649-678.

Dale K and Burrell G (2008) Spaces of Organization and the Organization of Space. Basingstoke, UK: Palgrave Macmillan.

Dale K and Burrell G (2011) Disturbing structure: Reading the ruins. Culture and Organization 17(2): 107-121.

Dale K and Burrell G (2015) Leadership and space in 3D: Distance, dissent and disembodiment in the case of a new academic building. In: Ropo A, Salovaara P, Sauer E and De Paoli D (eds) Leadership in Spaces and Places. Cheltenham, UK and Northampton, MA: Edward Elgar, pp. 217-241.

Denis J-L, Langley A and Sergi V (2012) Leadership in the plural. The Academy of Management Annals 6(1): 211-283.

De Paoli D, Sauer E and Ropo A (2017) The spatial context of organizations: A critique of creative spaces. Journal of Management \& Organization. Published online, 18 September. 
De Vaujany F-X and Vaast E (2014) If these walls could talk: The mutual construction of organizational space and legitimacy. Organization Science 25(3): 713-731.

Douglas T and Shamblin A (2009) The House That Built Me (Recorded by Miranda Lambert): On Revolution. New York, NY: Columbia Nashville.

Draht WH, McCauley CD, Palus CJ, Van Velsor E, O’Connor PMG and McGuire JB (2008) Direction, alignment, commitment: Toward a more integrative ontology of leadership. The Leadership Quarterly 19: 635-653.

Elsbach KD and Pratt MG (2007) The physical environment in organizations. The Academy of Management Annals 1(1): 181-224.

Fayard A-L and Weeks J (2007) Photocopiers and water-coolers: The affordances of informal interaction. Organization Studies 28(5): 605-634.

Feldman MS (2016) Making process visible: Alternatives to boxes and arrows. In: Langley A and Tsoukas H (eds) The SAGE Handbook of Process Organization Studies. London: Sage, pp. 625-635.

Fineman S (ed) (2000) Emotion in Organizations. London: Sage.

Fisher K and Reiser Robbins C (2015) Embodied leadership: Moving from leader competencies to leaderful practices. Leadership 11(3): 281-299.

Ford J, Hardy CH, Gilmore S and Richarson S (2017) Becoming the leader: Leadership as material presence. Organization Studies 38(11): 1553-1571.

Hansen H, Ropo A and Sauer E (2007) Aesthetic leadership. Leadership Quarterly 18: 544560.

Hawkins B (2015) Ship-shape: Materializing leadership in the British Royal Navy. Human Relations 68(6): 951-971.

Hernes T (2004) The Spatial Construction of Organization. Amsterdam, Netherlands: John Benjamins. 
Hernes T (2014) A Process Theory of Organization. Oxford, UK: Oxford University Press.

Hernes T, Bakken T and Olsen PI (2006) Spaces as process: Developing a recursive perspective on organizational space. In: Clegg SR and Kornberger M (eds) Space Organizations and Management Theory. Copenhagen, Denmark: Liber and Copenhagen Business School Press, pp. 44-63.

Humphries C and Smith ACT (2014) Talking objects: Towards a post-social research framework for exploring object narratives. Organization 21(4): 477-494.

Introna LD (2013) Otherness and the letting-be of becoming: Or, ethics beyond bifurcation. In: Carlile P, Nicolini D, Langley A and Tsoukas H (eds) How Matter Matters: Objects, Artifacts and Materiality in Organization Studies. Oxford, UK: Oxford University Press, pp. 260-287.

Jones M (2013) Untangling sociomateriality. In: Carlile P, Nicolini D, Langley A and Tsoukas H (eds) How Matter Matters: Objects, Artifacts and Materiality in Organization Studies. Oxford, UK: Oxford University Press, pp. 197-226.

Kastelein JP (2014) Space meets knowledge (abstract). Breukelen: Nijenrode Business School. Available at: http://www.ynno.com/wp-content/uploads/2014/01/SPACE-MEETSKNOWLEDGE-ABSTRACT.pdf (accessed 10 March 2017).

Ladkin D and Taylor SS (2010) Enacting the "true self": Towards a theory of embodied authentic leadership. Leadership Quarterly 21: 64-74.

Ladkin D and Taylor SS (eds) (2014) The Physicality of Leadership: Gesture, Entanglement, Taboo, Possibilities. Bingley, UK: Emerald.

Langley A and Tsoukas H (2016) Introduction. In: Langley A and Tsoukas H (eds) The SAGE Handbook of Process Organization Studies. London: Sage, pp. 1-25. 
Langley A, Smallman C, Tsoukas H and Van de Ven AH (2013) Process studies of change in organization and management: Unveiling temporality, activity, and flow. Academy of Management Journal 56(1): 1-13.

Latour B (2005) Reassembling the Social. An Introduction to Actor-Network Theory.

Oxford: Oxford University Press.

Lefebvre H (1991) The Production of Space. Oxford, UK: Blackwell.

Lefebvre H (2004) Rhythmanalysis: Space, Time and Everyday Life. London: Continuum.

Leonardi PM (2013a) The emergence of materiality within formal organizations. In: Carlile P, Nicolini D, Langley A and Tsoukas H (eds) How Matter Matters: Objects, Artifacts and Materiality in Organization Studies. Oxford, UK: Oxford University Press, pp. $142-170$.

Leonardi PM (2013b) Theoretical foundations for the study of sociomateriality. Information and Organization 23: 59-76.

Linstead S and Höpfl H (eds) (2000) The Aesthetics of Organization. London, UK: Sage.

Low SM and Altman I (eds) (1992) Place Attachment: A Conceptual Inquiry. New York: Plenum Press.

Martin PY (2002) Sensations, bodies, and the 'spirit of a place': Aesthetics in residential organizations for the elderly. Human Relations 55: 861-885.

Massey D (2005) For Space. London: Sage.

Melina LR, Burgess GJ, Falkman LL and Marturano A (eds) (2013) The Embodiment of Leadership. San Francisco, CA: Jossey-Bass.

Meretoja H (2014) The Narrative Turn in Fiction and Theory. London: Palgrave.

Merleau-Ponty M (2012) Phenomenology of Perception (Smith C, translation). New York, NY: Humanities Press.

Merrifield A (2000) Lefebvre. A socialist in space. In: Crang M and Thrift N (eds) Thinking 
Space. ProQuest Ebook Central. Abingdon, UK and New York, NY: Taylor and Francis, pp. 167-182.

Michel A (2014) The mutual constitution of persons and organizations: An ontological perspective on organizational change. Organization Science 25(4): 1082-1110.

Miller D (2005) Materiality. Durham, NC: Duke University Press.

Miller D (2008) The Comfort of Things. Cambridge, UK: Polity Press.

Oborn E, Barrett M and Dawson S (2013) Distributed leadership in policy formulation: A sociomaterial perspective. Organization Studies 34(2): 253-276.

Orlikowski WJ (2007) Sociomaterial practices: Exploring technology at work. Organization Studies 28: 1435-1448.

Orlikowski WJ and Scott SV (2008) Sociomateriality: Challenging the separation of technology, work and organization. The Academy of Management Annals 2(1): 433-474.

Orr J (1995) Talking about Machines: An Ethnography of a Modern Job. Ithaca, NY: Cornell University Press.

Pallasmaa J (2014) Space, place, and atmosphere: Peripheral perception in existential experience. In: Borch C (ed.) Architectural Atmospheres: On the Experience and Politics of Architecture. Basel, Germany: Birkhäuser, pp. 18-41.

Parry KW and Bryman A (2006) Leadership in organizations. In: Clegg SR, Hardy C, Lawrence TB and Nord WR (eds) The SAGE Handbook of Organization Studies. London, UK: Sage, pp. 447-468.

Pullen A and Vacchani S (2013) The materiality of leadership. Leadership 9(3): 315-319.

Puranam P, Alexy O and Reitzig M (2014) What's 'new' about new forms of organizing? Academy of Management Review, 39(2): 162-180.

Raelin J (2011) From leadership-as-practice to leaderful practice. Leadership 7(2): 195-211. Raelin J (ed) (2016) Leadership-As-Practice. Theory and Application. New York, NY: 
Routledge.

Redekop B (ed) (2010) Leadership for environmental sustainability. New York, NY and London, UK: Routledge.

Riessman C (2008) Narrative methods for human sciences. Thousand Oaks: Sage.

Ropo A and Höykinpuro R (2017) Narrating organizational spaces. Journal of Organizational Change Management 30(3): 357-366.

Ropo A and Parviainen J (2001) Leadership and bodily knowledge in expert organizations: Epistemological rethinking. Scandinavian Journal of Management 17(1): 1-18.

Ropo A, Parviainen J and Koivunen N (2002) Aesthetics in leadership: From absent bodies to social bodily presence. In: Meindl J and Parry K (eds) Grounding Leadership Theory and Research: Issues and Perspectives. Greenwich, CT: Information Age Publishing, pp. 21-38.

Ropo A, Salovaara P, Sauer E and De Paoli D (eds) (2015) Leadership in Spaces and Places. Cheltenham, UK and Northampton, MA: Edward Elgar.

Ropo A and Sauer E (2008) Corporeal leaders. In: Barry D and Hansen H (eds) The SAGE Handbook of New Approaches in Management and Organization. London: Sage, pp. 469-478.

Ropo A, Sauer E and Salovaara P (2013) Embodiment of leadership through material place. Leadership 9(3): 378-395.

Salovaara P (2014) Video: Leadership in Spaces and Places. Organizational Aesthetics 3(1), pp. 79-79.

Salovaara P and Ropo A (2013) Embodied learning experience in leadership development. In: Melina RL, Falkman LL and Marturano A (eds) The Embodiment of Leadership. San Francisco, CA: Jossey-Bass, pp. 193-215. 
Salovaara P and Ropo A (2018) Lefebvre and spacing leadership: from power over to power with. In: Kingma, S., Dale K. \& Wasserman, V. (eds) Organizational space and beyond: The significance of Henri Lefebvre for organizational studies. London: Routledge. In press.

Seamon D (1979/2015) A Geography of the Lifeworld. Abingdon, UK and New York, NY: Routledge.

Sergi V (2016) Who’s leading the way? Investigating the contributions of materiality to the study of leadership-as-practice. In: Raelin J (ed) Leadership-As-Practice: Theory and Applications. New York, NY: Routledge, pp. 110-131.

Shortt H (2015) Liminality, space and the importance of ‘transitory dwelling places’ at work. Human Relations 68(4): 633-658.

Shotter J (2006) Understanding process from within: An argument for 'withness'-thinking. Organization Studies 27: 585-604.

Simonsen K (2005) Bodies, sensations, space and time: The contribution from Henri Lefebvre. Geografiska Annaler: Series B, Human Geography 87(1): 1-14.

Sinclair A (2005) Body possibilities in leadership. Leadership 1(4): 387-406.

Sinclair A (2013) The material dean. Leadership 9(3): 436-443.

Special Issue on: ‘The Materiality of Leadership’ (2013). Leadership 9(3): 315-443.

Springborn C (2010) Leadership as art - leaders coming to their senses. Leadership 6(3): 243258.

Squire C (2013) From experience-centred to socioculturally-oriented approaches to narrative. In: Andrews M, Squire C and Tamboukou M (eds) Doing Narrative Research. London: Sage, pp. 47-71.

Strati A (1999) Organization and Aesthetics. London, UK: Sage. 
Strati A (2007) Sensible knowledge and practice-based learning. Management Learning 38(1): $61-77$.

Symon G and Pritchard K (2015) Performing the responsive and committed employee through the sociomaterial mangle of connection. Organization Studies 36(2): 241-263.

Taylor S and Spicer A (2007) Time for space: A narrative review of research on organizational spaces. International Journal of Management Reviews 9(4): 325-346.

Tsoukas H and Chia R (2002) On organizational becoming: Rethinking organizational change. Organization Science 13(5): 567-582.

Tuan YF (1977) Space and Place. The Perspective of Experience. Minneapolis, MN: University of Minnesota Press.

van Marrewijk A and Yanow D (eds) (2010) Organizational Spaces Rematerializing the Workaday World. Cheltenham, UK and Northampton, MA: Edward Elgar.

Wasserman W and Frenkel M (2015) Spatial work in between glass ceilings and glass walls:

Gender-class intersectionality and organizational aesthetics. Organization Studies 36(11): 1485-1505.

Wood M (2005) The fallacy of misplaced leadership. Journal of Management Studies 42(6): 11011121.

Wood M, Salovaara P and Marti L (2018). Manifesto for screen production in organisation studies. Organization. Article first published online: January 10,

2018 https://doi.org/10.1177/1350508417749886

Yanow D (2010) Giving voice to space: Academic practices and the material world. In: van Marrewijk A and Yanow D (eds) Organizational Spaces: Rematerializing the Workaday World. Cheltenham, UK and Northampton, MA: Edward Elgar, pp. 139-158.

Zhang Z (2006) What is lived space? Ephemera 6(2): 219-223. 
Zhang Z and Spicer A (2014) 'Leader, you first': The everyday production of hierarchical space in a Chinese bureaucracy. Human Relations 67(6): 739-762 


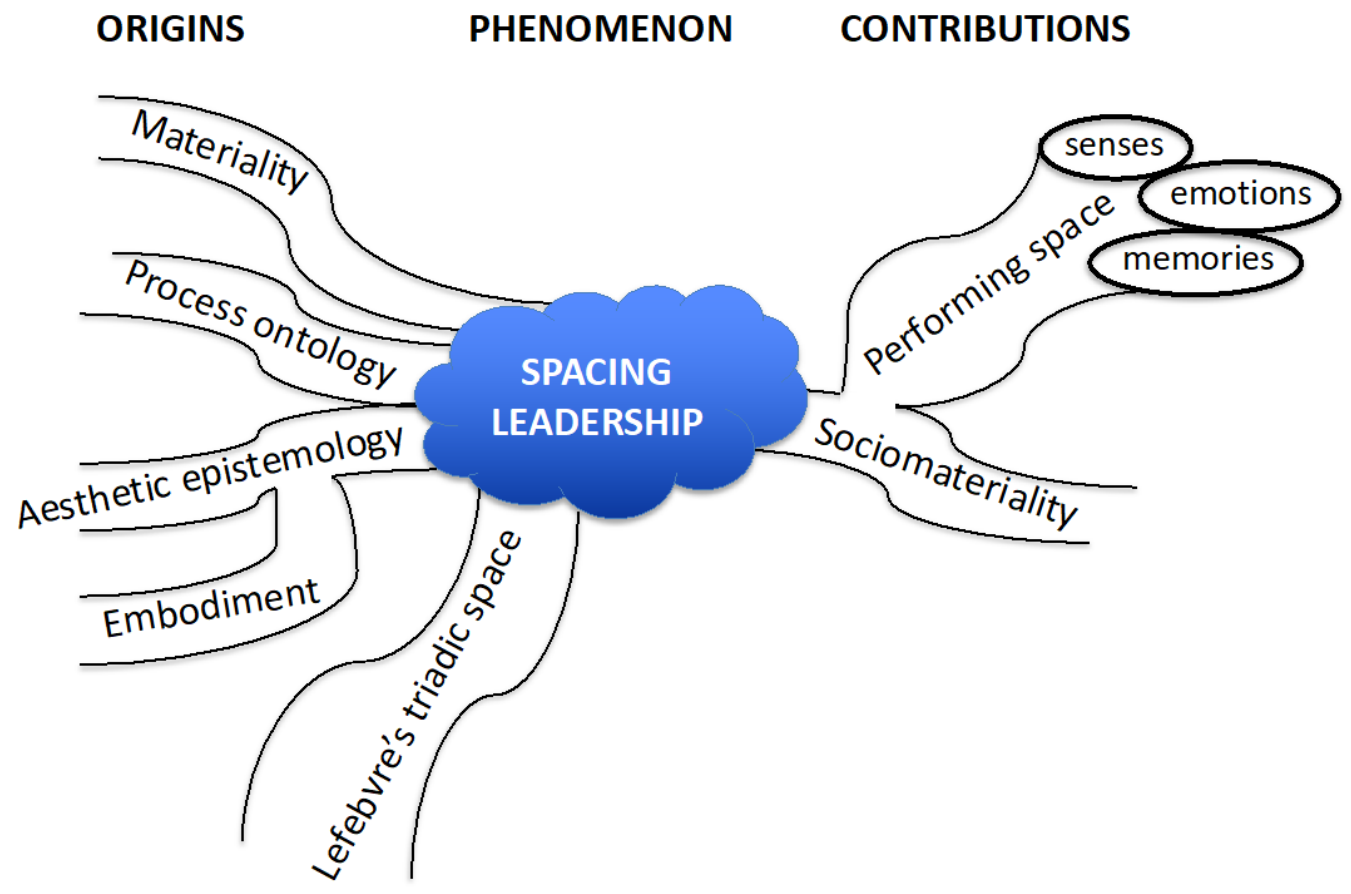

Figure 1. Spacing leadership: Origins and contributions to leadership theory 